\title{
An Investigation on Changing Behaviours of University Students Switching from Using Classical Cell Phones to Smartphones
}

\author{
Yusuf Arslan \\ Correspondence: Yusuf Arslan, Department of Sociology, University of Batman, Turkey. \\ Received: April 12, $2016 \quad$ Accepted: April 16, $2016 \quad$ Online Published: April 24, 2016 \\ doi:10.11114/jets.v4i6.1544 URL: http://dx.doi.org/10.11114/jets.v4i6.1544
}

\begin{abstract} from 450 students attending Batman University. phones to smartphones were noted and presented below:

a) Changes in total time spent in social network,

b) Changes in academic activities,

c) Changes in family communication,

d) Changes in social environment needs,

e) Changes in perceptions of developments around,

f) Changes in cell phone carrying susceptibility (cell phone addiction).
\end{abstract}

In this study, it was tried to comprehend whether there occur any changes in behaviours of university students switching from classical cell phones to smartphones. The investigation was carried out according to quantitative research method. Questionnaire was employed as data collection tool. The datum of the study was limited with the information gathered

According to the results of the study, the following changes in the behaviours of students switching from classical cell

Keywords: cell phone, classical Cell phone, smart phone, mobile communication, harms of smartphones, university students

\section{Introduction}

Means of communication have possessed a significant place in human life since ancient times. There has been a progressing process in means of communication from the drawings on the walls of caves to the communication means such as smoke, pigeons, messengers and letters. This progression, with non-stop speed, continued in XIX century as well; and when two Englishmen, William Cook and Charles Wheatstone, succeeded in sending electric current through wires, this development became one of the most remarkable steps in terms of communication tools. With Samuel Mors, who achieved to send the news by means of telegraph using Mors Codes in 1843, communication was carried further ahead. Moreover, invention of telephone by Graham Bell was the most important development in the history of communication. The fact that the first telephone did not have the property to be carried turned out to be a problem in later years. It became possible to carry these telephones after the addition of portability feature in 1973 when communications engineer, Martin Cooper, invented the first mobile phone of almost $1 \mathrm{~kg}$ weight whose electric charge could last just $20 \mathrm{~min}$. The sizes and weights of these cell phones were made smaller and lighter, respectively. These tools not having any other functions apart from communication and short message service (SMS) were called simple cell phones (Chow \& Chen \& Yeow \& Wong, 2012) or classical cell phones (Sanne, 2009). The difference between a classical cell phone and a smart phone is generally that a smart phone comprises various functional applications such as network connection, touchscreen, e-mail, game, and fax, pager (Zheng \& Ni, 2006:1). In other words, different from classical cell phones, smartphones have properties which enable their users to use computer, telephone and internet network system through one tool (Guo \& Wang \& Zhu \& 2004). Although smartphones are equipped with such operating systems as Windows Mobile, İPhone İOS, Symbian İOS, Google Android and Linux, none of these features is available with classical cell phones (Sanne, 2009). Being different from the classical cell phones, smartphones have the following properties (Ada \& Tatli, 2013):

- "Making phone calls and sending and receiving text messages 
- Possessing advanced connection options such as GPS, Wi-Fi, 3G, Bluetooth, FM

- Providing mobile internet connection

- Presenting an application market where one can upload mobile applications

- Having a mobile operating system on which applications can be developed

- Providing touchscreen interface

- Operable with more than one application at a time

- Having internal or appendable memory

- Possessing picture and sound recording".

With much more effective properties, new generation smartphones with thoroughly developed operating systems appeared on the markets in 2000s (Taner, 2013). "Having additional properties such as high memory capacity and operating power in developing internet, smartphones made a great progress in 2000s (Gokaliler \& Aybar \& Guler, 2011:39); therefore, they were called as "wonderful technologies" due to the fact that they have the properties possessing all instruments each of which is naturally unique; for instance, oral and written communication, CD and DVD player, radio, camera, photograph machine, type writer, notebook, calculator, calendar, pager, newspaper, TV etc.

Usage of smartphones by the individuals cannot be attributed to merely one reason. The intended purpose of using these devices may change from person to person (Chow \& Chen \& Yeow \&Wong, 2012). There are researches showing the fact that many individuals prefer smartphones since these devices meet their social and emotional needs in online platforms (Ting \& Lim \& Patanmacia \& Low \& Ker, 2011; Lane and Manner, 2011; Lunden, 2012). Smartphones are preferred because of the advantages that their "augmented reality"l applications provide benefits, for example, influence of family and social environment (Park \& Chen, 2007), social wannabe (Klobas \& Clayde, 2001), sign of status (Clark \& Zboja \& Goldsmith, 2007) besides fields such as trade, education, health, publication, media, marketing (Koroglu: 2010; Chen \& Park \& Putzer, 2010).

The datum shows that smart phone usage has increased rapidly in all over the world. In 2010, the number of smart phone users was 305 million, and in 2011, 494 million, in 2012, 725 million, in 2013, 1.04 billion, and finally in 2014, the number exceeded 1.2 billion users (www.IDCraport, 2014).

The number of smart phone users in Turkey is increasing rapidly year by year. In a survey conducted by Google (Consumer Barometer with Google: 2014), the ratio of the smart phone users was 14\% in 2012, 34\% in 2013, and it reached 39\% in 2014. In "Households Informatics Technologies Usage Survey" carried out by Turkish Statistics Institution (TUIK, 2015), it was determined that 96.8\% of Turkish families have either classical cell phones or smartphones. In the same survey, it was found out that $94.1 \%$ of individuals using smartphones were either university graduates or students (TUIK, 2015). Is it possible that these devices shape students' behaviours and habits? In this study, it was tried to understand whether the university students having switched from classical cell phones to smartphones have had any changes in their behaviours. The study, conducted with empirical data, may show that smartphones are likely to be the cause lying under some negative behaviours that the students demonstrate their parents, school administrators and academicians. The negatively affected population can make use of these data, and make their students become aware of the fact.

\section{Method}

In present study, quantitative research method is employed. Survey model is anticipated as research model. Survey models are "scanning arrangements carried out on a group of sample or sampling taken from a population consisting of many elements so as to reach a general conclusion about that population" (Karasar, 2009). Survey researches asking questions about a lot of variables in one session are convenient to observe the beliefs, opinions, traits of many people; and they produce statistical data as a necessity of their nature" (Neuman, 2012).

The population of survey consists of totally 8.500 students attending to associate and undergraduate degrees in Batman University. According to purposive sampling technique, 450 students were chosen as sampling population. While choosing these students, whether the chosen students have ever used classical cell phones and later smartphones was taken into consideration without paying any attention to their departments. According to this, each student has used a classical mobile phone and a smartphone, afterwards.

\footnotetext{
${ }^{1}$ Augmented reality is an event where an environment or an element belonging to the physical world can be seen in a form as alive, direct or indirect; afterwards, it is the event where it is developed and enriched by adding these elements to perceptive inputs such as sound, graphics, GPS location information produced in informatics environment (Koroglu, 2010; 2012).
} 
Questionnaire was utilized in the study as a data collecting tool. Questionnaire was used due to its advantages such as allowing the participants sufficient time to think while answering the questions and enabling the surveyors to obtain information from more than one person in a short time. In the survey, 5 Likert questions were prepared in order to understand the change occurring in students' behaviours before and after using smartphones. The questions to be asked in survey took their final form after they were evaluated by two different academicians of the field in terms of their validity and reliability. While applying the questionnaire, the students were informed about the purpose of the study; and those who accepted to take part in were delivered questionnaire forms. The application of questionnaire was performed in Batman University campus in April and May, 2015.

The data obtained from the study were converted into quantitative data after their frequencies and percentages were calculated according to their categories. These data were tried to be commented on in line with the purpose of the study making use of literature. The data of the study may not be convenient for generalizing them out of this population since they are limited to Batman University students.

\section{Findings}

In each scientific study, some findings are obtained. The following findings were obtained from this study.

\subsection{Findings about Changes in Total Time of the Students' Using Social Networks}

The findings obtained from the study about changes in duration of the students' using social networks are as follows:

Table 1. Table about change in total time ${ }^{2}$ of students' using social networks

\begin{tabular}{|c|c|c|c|c|c|c|c|c|c|c|c|c|}
\hline $\begin{array}{c}\text { Classical } \\
\text { Cell phones }\end{array}$ & $\begin{array}{c}\text { Betwee } \\
\text { n 0-1 } \\
\text { hour }\end{array}$ & $\%$ & $\begin{array}{c}1 \text { hour } \\
\& \\
\text { more } \\
3 \text { hours }\end{array}$ & $\%$ & $\begin{array}{c} \\
\text { hours } \\
\& \\
\text { more } \\
-5 \\
\text { hours }\end{array}$ & $\%$ & $\begin{array}{c}5 \text { hours } \\
\& \text { more } \\
-7 \\
\text { hours }\end{array}$ & $\%$ & $\begin{array}{c}7 \text { hours } \\
\text { and } \\
\text { more }\end{array}$ & $\%$ & Total & $\%$ \\
\hline Facebook & 257 & 57.1 & 121 & 26.9 & 43 & 9.6 & 18 & 4 & 11 & 2.4 & 450 & 100 \\
\hline Twitter & 81 & 18 & - & - & - & & - & & - & & 81 & 18 \\
\hline
\end{tabular}

\begin{tabular}{|c|c|c|c|c|c|c|c|c|c|c|c|c|}
\hline $\begin{array}{l}\text { Smart } \\
\text { phones }\end{array}$ & $\begin{array}{l}\text { Betw } \\
\text { een } \\
0-1 \\
\text { hour }\end{array}$ & $\%$ & $\begin{array}{l}1 \\
\text { hour } \\
\& \\
\text { more } \\
-3 \\
\text { hours }\end{array}$ & $\%$ & $\begin{array}{l}3 \text { hours } \\
\& \text { more } \\
-5 \text { hours }\end{array}$ & $\%$ & $\begin{array}{l}5 \text { hours } \\
\text { \&more- } \\
7 \text { hours }\end{array}$ & $\%$ & $\begin{array}{l}7 \text { hours } \\
\& \text { more }\end{array}$ & $\%$ & Total & $\%$ \\
\hline Facebook & 102 & 22.7 & 141 & 31.3 & 95 & 21.1 & 51 & 11.3 & 61 & 13.6 & 450 & 100 \\
\hline Twitter & 101 & 22.4 & 37 & 8.2 & - & & - & & - & & 138 & 30.6 \\
\hline
\end{tabular}

"Social sharing networks are web based services which allow individuals to create a profile open to all or semi open within a limited system, and demonstrate other users' lists in connection clearly, and show the list of people in connection with the others in the system" (Danah \& Nicola, 2007). There are millions of young members of these web sites; and these sites have changed into platforms where young people spend hours without getting bored all day long (Karli, 2010:206). Accordingly, while the rate of students being online during the period when they used classical cell phones was $57.1 \%$ on average for $0-1$ hour on Facebook, it dropped to $22.7 \%$, and the rate of being online for 1 hour and more but less than 3 hours increased from 26.9 to 31.3, and the rate of being online for 3 hours and more but less than 5 hours from $9.6 \%$ to 21.1, and the rate of being online between 5 hours and 7 hours increased from $4 \%$ almost 3 times as $11.3 \%$, and the rate of being online for 7 hours and more increased more than 6 times from $2.4 \%$ to $13.6 \%$. According to these findings, it can be seen that smartphones have obviously increased the duration of Facebook usage. The fact that 550 million people in the world and 15 million people in Turkey become online to Facebook by means of smartphones substantiates the results of this study (www.hurriyet.com.tr). The studies carried out in Turkey demonstrate that Facebook is the mostly preferred social sharing network (Karli, 2010). Facebook has a high popularity among students since it has functions such as "status", "Search for Friend", "Poking", "Photo/Video sharing", "Albums",

\footnotetext{
${ }^{2}$ In the survey, the students were asked about the total time of their using social network in a week [7 days]. So the data in Table 2 can explain only a week of social network usage rates of the students.
} 
"Groups", “Activities”, “Labelling”, “Writing Text Message”, and also it meets several needs; for example, making aware of common friends' sharing, sending notes and homework to each other. The students have recently started to head for WhatsApp since it spread among students.

Since the number of students using Twitter was low, the number of students answering this category turned out to be limited. However, the responds submitted give us an idea. The rate of the ones who stated that they used twitter through their classical cell phones between $0-1$ hour increased from $18 \%$ to $22.4 \%$ and the rate of ones who used it between 1 hour and more and less than 3 hours was determined to be $8.2 \%$. This datum shows that smartphone usage has also increased the total time of twitter usage. Especially, Twitter has become a network whose popularity has been increasing as the celebrities have started to use this site and broadcast their opinions and feelings through it (Karli, 2010).

\subsection{Findings about Changes in Academic Activities of Students}

In the study carried out, three different findings about smartphones were obtained in terms of academic activities of students:

a) The changes in their studying period,

b) The changes in their interest in listening to lesson,

c) The changes in their reading habits.

These are as follows, respectively.

\subsubsection{Findings about Changes in Total Time Students Allocated for Studying}

Findings about how smartphones affected students' studying time are as in Table 2.

Table 2. Table about Changes in Studying Hours of Students

\begin{tabular}{|c|c|c|c|c|c|c|c|c|c|c|c|c|}
\hline $\begin{array}{l}\text { It led to } \\
\text { decrease in } \\
\text { total time I } \\
\text { allocated to } \\
\text { study. }\end{array}$ & 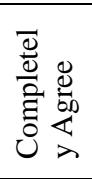 & $8^{\circ}$ & 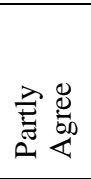 & $\theta^{\circ}$ & 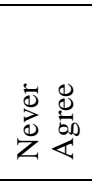 & $b^{\circ}$ & 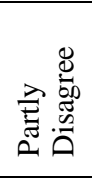 & $b^{\circ}$ & $\begin{array}{l}\frac{\pi}{0} \\
0 \\
0 \\
z\end{array}$ & $\delta^{\circ}$ & $\stackrel{\pi}{0}$ & $b^{\circ}$ \\
\hline $\begin{array}{l}\text { Classical } \\
\text { Cell phones } \\
\end{array}$ & 127 & 28.2 & 132 & 29.3 & 103 & 22.9 & 57 & 12.8 & 31 & 6.8 & 450 & 100 \\
\hline Smartphones & 205 & 45.6 & 114 & 25.3 & 73 & 16.2 & 44 & 9.8 & 14 & 3.1 & 450 & 100 \\
\hline
\end{tabular}

According to the table, while the rate of the students who "Completely Agree" the opinion that classical cell phones decrease the total time allocated for studying was $28.2 \%$, the rate was almost doubled increasing to $45.6 \%$ with smartphones. This datum reveals that smartphones decrease the total time allocated for studying. The fact that the students spend a lot of time on internet, especially, on social networks naturally, leads to decrease in the time they allocate for studying. In studies performed in the US, the increasing usage of smartphones besides TV and computers showed that they caused restrictions in total time allocated for reading and studying lesson (Brant: 2003). The fact that the number of the students who "never agree" this opinion dropped from $22.9 \%$ to $16.2 \%$ reinforces the view that smartphones limit the duration of studying.

\subsubsection{Findings about Changes in Students' Interest in Listening to Lessons}

Findings obtained about whether smartphones have a negative impact on students' listening to their lessons are as in Table 3 .

Table 3. Table about Students' Interests in Listening to Lesson

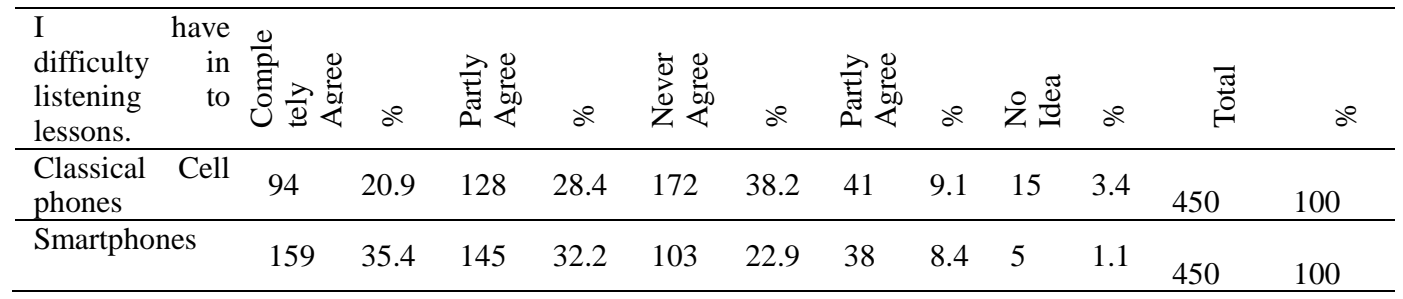

According to Table 3, while the number of the students who "Completely Agree" the idea that classical cell phones affect listening to lesson negatively was $20.9 \%$, it is observed that the rate increased $35.4 \%$ after they started using smartphones. This finding reveals that smartphones affect their interest in listening to lesson in negative way. Despite the fact that the student is in the class, he cannot help not to check or use his smart phone, which may cause to lose attention, reduce the interest in the lesson and have low concentration. There are studies proving this. In their study, Gill \& Kamath \& Gill (2012) stated that smartphones may have negative results on students' attention and concertation since 
they force the individuals to look for activities that they can continually linger with. In a study that Microsoft carried out with more than two thousand participants using smartphones and portable devices, it was found out that the attention period of individuals can drop to 8 seconds (Microsoft Report: 2015). These results empower the validity of the findings in the table.

\subsubsection{Findings about Changes in Students' Reading Habits}

In the study, the findings obtained about whether there is reduction in reading habits of students are as in Table 4:

Table 4. Table about Changes in Students' Reading Habits

\begin{tabular}{|c|c|c|c|c|c|c|c|c|c|c|c|c|}
\hline $\begin{array}{l}\text { My reading } \\
\text { habit was } \\
\text { negatively } \\
\text { affected }\end{array}$ & 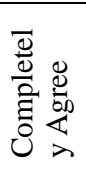 & $b^{\circ}$ & 总远 & $b^{2}$ & 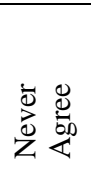 & $d^{2}$ & 总导 & $d^{2}$ & $\begin{array}{l}\frac{\mathscr{d}}{0} \\
\stackrel{0}{Z}\end{array}$ & $d^{0}$ & 氶 & $b^{\circ}$ \\
\hline $\begin{array}{l}\text { Classical } \\
\text { Mobile } \\
\text { Phone } \\
\end{array}$ & 81 & 18 & 77 & 17.1 & 192 & 42.7 & 77 & 17.1 & 23 & 5.1 & 450 & 100 \\
\hline $\begin{array}{l}\text { Smart } \\
\text { Phone }\end{array}$ & 230 & 51.1 & 101 & 22.4 & 73 & 16.3 & 33 & 7.3 & 13 & 2.9 & 450 & 100 \\
\hline
\end{tabular}

According to the data given in Table 4, while the rate who "completely Agree" the idea that classical cell phones influence students' reading habits negatively was $18 \%$, it was understood that this rate increased more than four times to $51.1 \%$ after they started using smartphones. This data clearly show that using smartphones can negatively affect the students' reading habits. The fact that the rate of students who expressed that they "Partly Agreed" the idea increased from $17.1 \%$ to 22.4 and that the rate of the students who stated that they "Never Agree" decreased almost three times from $42.7 \%$ to $16.3 \%$ support these data indirectly. This truth has been revealed in numerous studies (Gallik, 1999; Aksaclıoğlu \& Yılmaz, 2007; Aranson, 2007). Smartphones may negatively direct not only students' reading habits but also their desires to read in their spare times (Kern, 2006). They seem to appreciate new habits such as games, chatting since they find them more attractive.

\subsection{Findings about Changes in Students' Family Communication}

The findings obtained about changes in students' family communication are as follows:

Table 5. Table about Changes in Students' Family Communication

\begin{tabular}{|c|c|c|c|c|c|c|c|c|c|c|c|c|}
\hline $\begin{array}{l}\text { I started to } \\
\text { experience } \\
\text { problems } \\
\text { in-family } \\
\text { communication. }\end{array}$ & 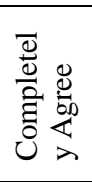 & $b^{\circ}$ & 离导 & $b^{\circ}$ & 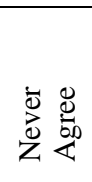 & $b^{0}$ & 氞导 & de & $\begin{array}{l}\frac{\pi}{0} \\
0 \\
z\end{array}$ & $a^{\circ}$ & 苞 & $b^{\circ}$ \\
\hline $\begin{array}{l}\text { Classical } \\
\text { Phone }\end{array}$ & 87 & 19.3 & 81 & 18 & 189 & 42 & 41 & 9.1 & 52 & 11.6 & 450 & 100 \\
\hline Smart Phone & 173 & 38.4 & 121 & 26.9 & 99 & 22 & 36 & 8 & 21 & 4.7 & 450 & 100 \\
\hline
\end{tabular}

According to the data given in Table 5, while the rate of the students who "Completely Agree" the idea that classical cell phones affect their in-family communication in negative way was $19.2 \%$, after the usage of smartphones this rate doubled as $38.4 \%$. This shows that smartphones may have the risk leading to negative results in family communication. According to the table, that the rate of "Partly Agree" increased from 18\% to $26.9 \%$ and that the number of "Never Agree" decreased nearly twice from $42 \%$ to $22 \%$ also strengthen this idea. The students who are insistently interested in their smartphones at home either limit their communication with their family members or they react to them very indifferently. For a moment, they may even forget that the ones whom they communicate are their parents. Their carelessness may lead to family conflicts or create a sensitive and fragile atmosphere among the family members (TBMM -Turkish Grand National Assembly- Informatics and Internet Research Commission Report: 2012). These devices, in some cases, may sometimes become sheltering areas for the students to run away from responsibilities. "For solution of communication problems, these devices are used to forget the problems instead of trying to solve; on the other hand, the problem a person faces is getting bigger and bigger; afterwards, these problems change into too big problems for an individual to cope with (Calıskan \& Aslanderen, 2014).

\subsection{Findings about Changes in Students'Social Environment Needs}

In the study carried out, the following findings were obtained in terms of the students' needs of the social environment: 
Table 6. Findings about Changes in Students' Social Environment Needs

\begin{tabular}{|c|c|c|c|c|c|c|c|c|c|c|c|c|}
\hline $\begin{array}{l}\text { My need to } \\
\text { social } \\
\text { environment } \\
\text { has decreased. }\end{array}$ & 芯 & $d^{0}$ & 槖莕 & $b^{0}$ & 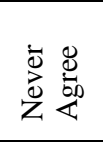 & $a^{2}$ & 离导 & $b^{\circ}$ & 之导 & $a^{2}$ & స్తేర & $b^{\circ}$ \\
\hline $\begin{array}{l}\text { Classical Cell } \\
\text { Phone }\end{array}$ & 113 & 25.1 & 74 & 16.4 & 198 & 44 & 62 & 13.8 & 33 & 7.3 & 450 & 100 \\
\hline Smart Phone & 201 & 44.7 & 95 & 21.1 & 86 & 19.1 & 56 & 12.4 & 12 & 2.7 & 450 & 100 \\
\hline
\end{tabular}

According to the data above, while the rate of the students who "Completely Agree" the idea that classical cell phones decrease the need for a social environment in students was $25.1 \%$, this rate increased a little less than twice as $44.7 \%$ after the students started to use smartphones. These data show that smart phone may decrease the need for a social environment. That the rate of "partly agree" increased from $16.4 \%$ to $21.1 \%$, and that the number of the students who "never agree" decreased approximately more than twice from $44 \%$ to $19.1 \%$ also strengthen this idea. No matter how much Hart and Blackshaw (2006) and Clark (2001) defend that these devices contribute to socialization, there are results of studies that show they decrease social capacity of individuals owing to lowering the individuals' face to face interaction (Nie, 2001). According to the data of present study, these devices have the risk of changing the students into an asocial character.

\subsection{Findings about Changes in Students' Perception about Environmental Developments}

In the study, the following results were obtained about changes in students' perception about their environment:

Table 7. Table about Changes in Students' Perception about Environmental Developments

\begin{tabular}{|c|c|c|c|c|c|c|c|c|c|c|c|c|}
\hline $\begin{array}{l}\text { My interest in } \\
\text { my } \\
\text { environment } \\
\text { has decreased. }\end{array}$ & 冚 & $b^{\circ}$ & 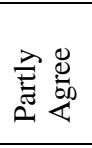 & $a^{2}$ & 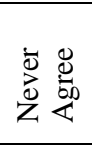 & $b^{\circ}$ & 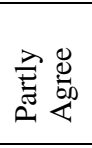 & $b^{\circ}$ & 之㞧 & $\theta^{\circ}$ & 吾 & $b^{2}$ \\
\hline $\begin{array}{l}\text { Classical Cell } \\
\text { Phone }\end{array}$ & 112 & 24.9 & 75 & 16.7 & 213 & 47.3 & 32 & 7.1 & 18 & 4 & 450 & 100 \\
\hline Smart Phone & 237 & 52.7 & 79 & 17.5 & 88 & 19.6 & 35 & 7.8 & 11 & 2.4 & 450 & 100 \\
\hline
\end{tabular}

According to the data given in table 7, while the rate of the students who "completely agree" the idea that classical cell phones decrease the interest in environmental changes was 24.9\%, it was understood that this rate increased $52.7 \%$ which was a little more than double after they started using smartphones. This finding sets forth that smartphones can decrease the students' interests in environmental changes and developments. That the number of students who "never agree" decreased from $47.3 \%$, a little more than double, to $19.6 \%$ can be interpreted as a proof supporting this idea. Smartphones may not always provide awareness for the community and environment in which people live. When overused, these devices may change into devices that lead the individuals to be indifferent to social and environmental values, loneliness and selfishness (Ellison \& Steinfield \& Lampe, 2007).

\subsection{Findings about Changes in Students' Mobile Phone Carrying Sensitivity (Device Dependence)}

The following findings were obtained about whether students felt addiction to cell phones or not:

Table 8. Findings about Changes in Students' Mobile Phone Carrying Sensitivity

\begin{tabular}{llllllllllllllll}
\hline $\begin{array}{l}\text { When my mobile } \\
\text { phone is not with me/ } \\
\text { runs out of charge, I } \\
\text { feel unhappy. }\end{array}$ \\
$\begin{array}{l}\text { Classical Cell Phone } \\
\text { Smart Phone }\end{array}$ & 154 & 34.2 & 100 & 22.2 & 108 & 24 & 65 & 14.3 & 23 & 5.1 & 450 & 100 \\
\end{tabular}

According to the data given in Table 8, while the rate of students who expressed their view that they "completely agree" the idea that they feel themselves unhappy when they forget to take their cell phones or they run out of charge while using classical mobile phone was $34.2 \%$, it can be seen that this rate nearly doubled as $63.6 \%$ with students who use smartphones. This datum demonstrates that the students' susceptibility to smartphones is higher than classical cell phones. There are studies revealing that device dependence among the youth is $78 \%$ (http://dergi.bmo.org.tr). Some adults were seen to have device dependence at obsessive and compulsive levels (Young, 1998; Young 1999). There may be some cases where these devices are not tools but purposes. It has still been discussed by some whether satisfaction of people to be together causes this addiction or device dependence prevents people to come together (Caliskan \& Aslanderen, 2014). However, some others argue that there occurs a mutual relation and a vicious circle (Acat, 2012). 


\section{Discussion}

We cannot deny the benefits that smartphones have on our personal and social lives. These phones described as 'Wonderful Technologies' have both benefits and harms. Although they have benefits such as facilitating life and making people access to information, they, however, may have harms on students such as leading behavioural changes which families of students and their teachers do not like to encounter. These behavioural changes present risks ranging from device dependence (Young, 1999) to selfishness (Ellison \& Steinfield \& Lampe, 2007), being asocialized (Nie, 2001); and from decrease in reading (Kern, 2006) to increase in family conflict (TBMM -Turkish Grand National AssemblyInformatics and Internet Research Commission Report, 2012), academic problems (Brant, 2003), wasting time in social networks (Karli, 2010), becoming insensitive to society and environment. This case may irritate families and teachers. They always want what is good for their children in order to protect them against the risks of these devices. There are some among them believing that the only way to protect them is to prohibit using the devices, on the other hand, there are others who defend that prohibition will be useless. The ones who defend the first idea may have ignored the relation between technology and learning. If these devices are properly used, they can offer students some personal and social opportunities.

\section{Conclusion}

In this study, it is revealed that there are some evidences about the possibility that smartphones can negatively shape the behaviours and habits of individuals. Not only students but also other individuals using smartphones have exhibited some changing behaviours and habits. Parents and teachers have also become interested in smartphones at least as much as students. They also have started to spend most of their time online using smartphones. In this digital age, all these are quite understandable; however, as a society, we have to keep in mind that these devices have harms as much as benefits. Particularly, it is a crucial responsibility to raise awareness in young generations about risks of these devices. It is essential that they realize that these devices can lead to some harmful behaviour and habits rather than beneficial ones when not handled carefully. This can be realized by means of 'conscious user education'. That parents, teachers and students can use smartphones peacefully, pleasantly and comfortably depends on the success of this education.

\section{References}

Acat, M. (2012). In Family Coherent Interaction. TR Eskisehir Anadolu University Open Faculty Pub., No: 1654.

Ada, S., \& Tatli, S. H. (2013). A Survey on Factors Affecting Smart phone Usage, Academic Informatics, Akdeniz University Pub., 1-7.

Aksaclioglu, A. G., \& Yilmaz, B. (2007). Effect of Students' Watching Television and Using Internet on their Reading Habits. Turkish Librarianship, 21(1), 3-28.

Aronson, M. (2007). Do Books Still Matter?. School Library Journal, 36-41.

Brandt, M. (2003). Log on and Learn. Newsweek, 25 August-1 September, 52-55.

Calıskan, N., \& Aslanderen, M. (2014). In -Family Communication and Cyber Life: A Theoretical Analysis. Ahi Evran University, Kirsehir Education Faculty Journal (KEFAD), 15(2), 263-277.

Chen, J., Park, Y., \& Putzer, J. G. (2010). An Examination of the Components that Increase Acceptance of Smartphones among Healthcare Professionals. Electronic Journal of Health Informatics, 5(2), 1-16.

Chow, M. M., Chen, L. H., \& Yeow, J. A., \& Wong, P. A. (2012). Conceptual Paper: Factors Affecting the Demand of Smartphone among Young Adult. International Journal on Social Science Economics \& Art, 2(2), 44-49.

Clark, R. A., Zboja, J. J., \& Goldsmith, R. E. (2007). Status Consumption and Role-Relaxed Consumption: A Tale of Two Retail Consumers, Journal of Retailing and Consumer Services, 14, 45-59. http://dx.doi.org/10.1016/j.jretconser.2006.03.003

Clark, T. (2001). Communities and Business: A New Way of Organizing. The Fourth International Conference on Virtual Communities, June 20-21. http://www.infonorties.com/vc/vc01/slides/clark_files/frame.htm

Consumer Barometer with Google (2014). https://www.consumerbarometer.com/en/insights/?countryCode=TR.

Danah, M. B., \& Nicole, B. E. (2007). Social Network Sites: Definition, History, and Scholarship. Journal of Computer-Mediated Communication, (13), 210-230.

Ellison, N. B., Steinfield, C., \& Lampe, C. (2007). The Benefits of Facebook Friend: Social Capital and College Students. Use of Online Social Network Sites Journal of Computer-Mediated Communication, 12, 1143-1168. E-Marketer.

Gallik, J. D. (1999). Do They Read For Pleasure? Recreational Reading Habits of College Students. Journal of 
Adolescent \& Adult Literacy, (3), 480-488.

Gill, P. S., Kamath, A., \& Gill, T. S. (2012). Distraction: An Assessment of Smartphone Usage in Health Care Work Settings. Risk Management and Healthcare Policy, 5, 105-114. http://dx.doi.org/10.2147/RMHP.S34813

Gokaliler, E., Aybar, A. S., \& Gulay, G. (2011). Perception of IPhone Brand Smartphones As an Indicator of Consumption Status: A study on University Students. Journal of Seljuk Communication, 7(1).

Guo, C., Wang, H. J., \& Zhu, W. (2004). Smart-Phone Attacks and Defences. In HotNets III. November.

Hart, C., \& Blackshaw, P. (2006). Internet Inferno. Marketing Management. (January-February), 19-25.

Karasar, N. (2009). Bilimsel Arastirma Yontemi. Ankara: Nobel. (Scientific Research Method. Ankara: Nobel).

Karli, I. (2010). "Medya Kuruluslari Sosyal Paylasim Aglarini Neden Kullanir?". ("Why Do Media Institutions Use Social Networks?”). 2'nd. International Conference of New Media and Interactivity Proceedings, International Conference of New Media and Interactivity. 28-30 April 2010. Istanbul., pp. 202-207.

Kern, R. (2006). Perspectives on Technology in Learning and Teaching Languages. TESOL Quarterly, 40(1), 183-210. http://dx.doi.org/10.2307/40264516

Klobas, J. E., \& Clyde, L. A. (2001). Social Influence and Internet Use. Library Management, 22(1), 61-67. http://dx.doi.org/10.1108/01435120110358943

Koroglu, O. (2010). The Most Common Nobel Communication Environment; Content and Broadcasting in Mobile Communication Environment, Civil academy Journal of Social Sciences, 8(2), 55-86.

Koroglu, O. (2012). Increased Reality Applications in the Most Common Environment. XVII Internet Conference in Turkey, 74-81.

Lane, W., \& Manner, C. (2011). The Impact of Personality Traits on Smartphone Ownership and Use. International Journal of Business and Social Science, 2(17), 22-28.

Lunden, I. (2012). If Content is King, Multiscreen is The Queen, Says New Google Study. TechCrunch. goo.gl/mvJLD

Microsoft Report (2015). Can We Have Your Attention Please? http://advertising.microsoft.com/en/attention-spans

Neuman, L. W. (2012). Social Research Methods; Quality and Quantitative Approaches I-II. Istanbul: Publication Chamber.

Park, Y., \& Chen, J. V. (2007). Acceptance and Adoption of the Innovative Use of Smartphone, Industrial Management and Data, 107(9), 1349-1365. http://dx.doi.org/10.1108/02635570710834009

Sanne (2009). What is the Difference Between a Smartphone and a Traditional Cell-phone? Retrieved. March (3). http://www.myce.com/mobile-phones/faq/what-is-the-difference-between-a-smartphone-and-a-traditional-cellphon e-21963/

Taner, N. (2014). The Evaluation of Smartphone Users: An Application in Kastamonu City Centre. Business \& Management Studies: An International Journal, 1(2), 127-140.

TBMM Bilisim ve Internet Arastirma Komisyonu Raporu (2012). (The Effects of Internet on in Family Communications).

Ting, D., Lim, S., Patanmacia, T., Low, C., \& Ker, G. (2011). Dependency on Smartphone and the Impact on Purchase Behaviour, Young Consumers: Insight and Ideas for Responsible Marketers, 12(3), 193-203. http://dx.doi.org/10.1108/17473611111163250

TUIK (2015) Hanehalki Bilisim Teknolojileri Kullanim Arastirmasi. (Householders Informatics Technologies Usage Research).

Young, K. S. (1998). Internet Addiction: The Emergence of a New Clinical Disorder. Cyber Psychology \& Behaviour, 1(3), 237-244. http://dx.doi.org/10.1089/cpb.1998.1.237

Young, K. S. (1999). Internet Addiction: Symptoms, Evaluation and Treatment. Innovations in Clinical Practice: A Source Book, 17, 19-31.

Zheng, P., \& Ni, L. M. (2006). Spotlight: The Rise of the Smart Phone. Distributed Systems Online, IEEE, 7(3). http://dx.doi.org/10.1109/mdso.2006.22

\section{$(\mathrm{OC}) \mathrm{BY}$}

This work is licensed under a Creative Commons Attribution 3.0 License. 